\title{
MATRIK
}

Jurnal Manajemen dan Teknik Industri-Produksi

Journal homepage: http://www.journal.umg.ac.id/index.php/matriks

\section{Restrukturisasi Mutu Air Bersih Dengan Teknologi Tepat Guna Ramah Lingkungan}

Moh. Dian Kurniawan

Program Studi Teknik Industri, Fakultas Teknik, Universitas Muhammadiyah Gresik

Jl. Sumatera 101 Gresik Kota Baru, Gresik (61121), Jawa Timur, Indonesia md.kurniawan@umg.ac.id

\begin{tabular}{l} 
INFO ARTIKEL \\
\hline $\begin{array}{l}\text { doi: } \mathbf{1 0 . 3 5 0 5 8 7 / M a t r i k} \\
\text { v18i2.589 }\end{array}$ \\
\hline Jejak Artikel : \\
Upload artikel \\
31 Juli 2020 \\
Revisi oleh reviewer \\
15 September 2020 \\
Publish \\
16 September 2020 \\
\hline
\end{tabular}

\section{Kata Kunci :}

QFD,HOQ, Mutu Air, water filter, Prototype water filter
ABSTRAK

Dalam kondisi saat ini khususnya daerah Kabupaten Gresik, yang sudah didominasi kawasan industri mengalami perubahan signifikan terhadap kondisi lingkungan yang berada disekitarnya, secara khusus kondisi perubahan dampak lingkungan terjadi pada kualitas air. Padahal air menjadi sumber utama kehidupan dan kebutuhan masyarakat luas untuk memenuhi hajatnya. Adanya perubahan warna maupun rasa pada sumber air yang berada di daerah gresik kawasan industri meliputi desa manyar, desa duduksampean maupun desa cerme, merupakan dampak akibat tercemarnya kondisi lingkungan yang menjadikan air sudah tidak murni lagi, karena sumber mata air maupun aliran air terkontaminasi oleh aktivitas limbah industri baik secara sengaja maupun tidak sengaja yang dilakukan oleh industri perusahaan yang berada diwilayah tersebut. Pada riset penelitian ini menemukan masalah yang terjadi pada kondisi kualitas air dengan 3 obyek yang diteliti antara lain desa manyar, desa duduksampean dan desa cerme, adapun tindakan yang dilakukan adalah melakukan survei tentang mutu air dari 3 obyek tersebut dengan menggunakan metode quality function deployment. Sehingga dapat memberikan solusi alternatif penanggulangan kualitas air tersebut bagi masyarakat yang berada di kawasan industri tersebut. hasil dari riset penelitian ini memberikan data berupa kriteria visual penampakan 3,77. Atribut visual warna 3,55. Dan atribut jenis air 3,53, PH diatas rata-rata batas normal 7,5.serta memiliki kandungan klorida yang tinggi mencapai 4,694.82 ng / L. maka alternatif solusi untuk memperbaiki mutu air adalah dengan pembuatan produk water pump filter untuk mengembalikan kondisi air yang lebih baik dan jernih, sehingga layak digunakan oleh masyarakat secara luas sesuai dengan pertimbangan data penelitian 


\section{Pendahuluan}

Penyediaan prasarana air bersih, termasuk dalam komponen Program Pembangunan Prasarana Kota Terpadu (P3KT) yang menjadi tanggung jawab Departemen Pekerjaan Umum (saat ini kementrian). Pengelolaan penyediaan air bersih dilakukan melalui kegiatan pengambilan bahan baku air, pengolahan air dan penyaluran air bersih ke pelanggan dalam hal ini warga kabupaten Gresik, namun realitanya tidak semua warga mendapatkan dan menikmati air bersih yang berada di masing-masing desa. Sehingga melalui penelitian dengan melakukan restrukturisasi air bersih menggunakan alat teknologi tepat guna yang ramah lingkungan diharapkan mampu mengatasi permasalahan tersebut. Terdapat 3 daerah yang menjadi sasaran obyek penelitian antara lain desa cerme, desa duduk sampeyan dan desa manyar yang berada di wilayah kabupaten Gresik, dikawasan tersebut banyaknya keluhan warga akan air bersih. Tidak sedikit warga harus membeli air bersih dari tempat lain yang didistribusikan melalui mobil tanki air bersih, tentu ini akan menjadi beban warga dari sisi biaya pembelian air bersih dalam memenuhi kebutuhan sehari-hari.

Dari latar belakang permasalahan tersebut, maka peneliti perlu melakukan sebuah uji alat teknologi tepat guna dan ramah lingkungan yang besar harapan dapat membantu warga masyarakat Gresik mendapatkan supply air bersih dalam memenuhi kebutuhan sehari-harinya skala rumah tangga yang bisa dibuat dan diproses sesuai kebutuhan masing-masing warga Gresik. Dengan konsep yang diusung peneliti diharapkan dapat membantu kesulitan air bersih bagi warga tanpa harus bergantung kepada pemerintah daerah (red: Pemda Gresik) sepenuhnya. Karena masyarakat mampu membuat, mengolah, memproduksi air bersih secara mandiri dengan alat-alat sederhana yang ramah lingkungan. Serta mudah ditemukan disekitar tempat tinggal mereka.

Prinsip dari penelitian ini adalah melihat kondisi air yang berada di wilayah Gresik khususnya yang berada di desa manyar, desa duduk sampeyan dan desa cerma untuk dilakukan pengelolaan air bersih yaitu mengubah mutu air yang tidak sesuai dengan keinginan kita menjadi mutu air berkualitas baik dengan layak untuk mandi,cuci, dan masak bagi warga Gresik.

\section{Tinjauan Pustaka}

2. 1. Kualitas

Mutu atau kualitas merupakan isu yang dominan pada banyak perusahaan, bersamaan dengan waktu yang pesat, fleksibilitas dalam memenuhi permintaan konsumen (produk yang dibuat selalu sesuai dengan apa yang diminta konsumen) dan harga jual yang rendah, mutu merupakan pilihan kunci dan strategis (Afnina, 2018). Kotler dan Armstrong (2013) berpendapat bahwa kemampuan sebuah produk memperagakan fungsinya, hal itu termasuk keseluruhan durabilitas, reliabilitas, ketepatan, kemudahan pengoperasian dan reparasi produk juga atribut produk lainnya. Dari pengertian tersebut disimpulkan bahw pengertian produk yang berkualitas adalah produk yang dapat memenuhi kebutuhan pelanggan atau menawarkan pelanggan atau menawarkan karakteristik yang lebih baik tetapi juga tidak memiliki kekurangan yang mengurangi kepuasan pelanggan. Konsumen tidak selalu mengatakan apa yang mereka inginkan dan banyak produk yang kurang berhasil karena kegagalan dalam memahami aspek-aspek yang sesungguhnya bernilai bagi pelanggan mereka seperti kualitas produk yang handal (Umar, 2015) Menjelaskan indikator yang terkait dengan kepuasan konsumen menurut (Setyo, 2017:755) yaitu :

1. Terpenuhinya harapan konsumen

2. Sikap atau keinginan untuk menggunakan Produk

3. Merekomendasikan kepada pihak lain

4. Kualitas layanan

5. Loyal

6. Reputasi yang baik

7. Lokasi

2.2 Pengukuran Kualitas

Kualitas dapat diukur melalui penelitian mengenahi persepsi konsumen terhadap kualitas suatu produk atau perusahaan (Tjiptono, 2002). Salah satu metode yang dapat digunakan untuk melakukan penelitian tersebut adalah survey kepuasan konsumen.

2.3 Pengembagan Produk

Pengembangan produk adalah rangkaian proses yang diawali dengan analisis persepsi dan peluang pasar dan sebagi tahap akhir adalah prosduksi, 
penjualan dan pengiriman produk yang dianggap memiliki nilai lebih dibandingkan dengan produk terdahulu (Ulrich,2001). Pengembangan produk merupakan salah satu strategi untuk bertahan dalam tingkat persaingan yang semakin ketat dan sekaligus juga meningkatkan kepuasan konsumen, beberapa dimensi yang digunakan sebagai parameter pengembangan produk yang sukses adalah (Ulrich, 2001) :

a. Menghasilkan laba

b. Kuliatas produk yang semakin baik, yang berarti juga harus meningkatkan kepuasan konsumen

c. Biaya produk lebih rendah, biaya produk berpengaruh terhadap laba yang dihasilkan.

d. Waktu pengambangan produk yang cepat menunjukan kemampuan perusahaan untuk berkompetisi

e. Biaya pengembangan, semakin rendah biaya pengembangan maka semakin baik

f. Kapabilitas pengembangan adalah modal untuk mengembangakan produk.

\subsection{Air Bersih}

Penyelenggaraan pelayanan prasarana dan sarana lingkungan pemukiman, termasuk diantaranya adalah penyediaan air bersih menjadi tugas dan tanggung jawab Pemerintah Kabupaten/Kota, sesuai dengan UU No. 23 Tahun 2014 yang mengatur tentang Pemerintah Daerah. Penyediaan dan pemenuhan kebutuhan air bersih dapat dilakukan dengan sistem perpipaan maupun sistem non perpipaan tergantung dari sumber air baku, sarana, dan prasarana di wilayah tersebut. Sistem perpipaan dikelola oleh Perusahaan Daerah Air Minum (PDAM) dan sistem non perpipaan dikelola oleh masyarakat baik secara individu maupun secara kelompok.

Pengolahan air bersih atau pretreatment merupakan hal utama yang harus diperhatikan dalam menghasilkan air bersih maupun air minum. Tirta mandiri merancang system pengolahan air bersih terpadu yang ekonomis dan tepat guna. Media yang dipakai untuk pengolahan air bersih disesuaikan dengan kebutuhan masyarakat. Dari media lokal sampai media import yang dipakai untuk menghasilkan air dengan kualitas terbaik. Beberapa media yang digunakan dalam sistem pengolahan air bersih bahkan sudah mendapatkan sertifikasi halal dari Majelis Ulama Indonesia (MUI) seperti karbon active, resin, filter maupun beberapa sparepart lainya.

Beberapa jenis air yang memiliki cara pengelolaan yang berbeda, antara lain :

a. air tanah yang besi dan mangan nya tinggi-dapat dilakukan pengelolaan air dengan menggunakan media manganese.

b. air tanah yang kapurnya tinggi, kadar kapur dapat dihilangkan dengan menggunakan pertukaran ion kation atau resin kation.

c. air tanah yang berbau, berwarna dan berasa, dapat dihilangkan atau dikurangi dengan media karbon aktif.

d. air yang tingkat kekeruhanya tinggi, dapat digunakan media pasir silica dan sedimen catrige.

e. air gambut pengolahanya gambut mmenjadi air bersih dapat dilakukan dengan menggunakan resin organic.

f. air payau pengolahanya dapat dirubah menjadi air tawar dengan menggunakan teknologi Reserver Osmosis (RO)

g. Air laut dapat dirubah menjadi air tawar dengan menggunakan teknologi Recerver Osmosis (RO)

h. Air yang tercemar limbah dapat menjadi air besih dengan menggunakan teknologi clarifier, ultrafiltrasi atau Reserver osmosis, sehingga air yang diproses dengan alat tersebut menjadi air berstandart kualitas baik layak minum

i. air sungai juga proses pengolahanya untuk menjadi air yang berkualitas baik bisa menggunakan Reserver Osmosis

2.5 Teknik Pengumpulan Data

kualitas pengumpulan data berkaitan dengan cara yang dilakukan untuk mengumpulkan data. Ada tiga teknik mengmpulkan data yaitu interview (wawancara), kuisioner dan observasi (azizah, 2018). Kuisioner Yaitu merupakan teknik pengumpulan data yang dilakukan dengan membuat pertanyaan atau pernyataan tertulis, yang kemudian akan disebarkan kepada responden sejumlah 100 orang yang tersebar didesa manyar, desa duduksampean dan desa cerme secara acak (random) baik laki-laki maupun wanita dengan batasan usia antara 25 - 40 tahun, jawaban dari responden tersebut yang kemudian akan menjadi data. Sedangkan 
untuk sample kualitas air dilakukan teknik observasi di tiga desa antara lain desa manyar, desa duduksampean dan desa cerme.Skala yang digunakan dalam kuisioner menggunakan skala 4 poin dengan meniadakan poin netral atau biasa. Skala ini digunakan untuk melihat kecenderungan pendapat responden ke arah penting atau tidak penting dan puas atau tidak puas.

Tabel 1. Skala Tingkat Kepentingan

\begin{tabular}{|l|c|}
\hline Tingkat Kepentingan & Poin \\
\hline Sangat Penting & 4 \\
\hline Penting & 3 \\
\hline Tidak Penting & 2 \\
\hline Sangat Tidak penting & 1 \\
\hline
\end{tabular}

Tabel 2. Skala Tingkat Kepuasan

\begin{tabular}{|l|c|}
\hline Tingkat Kepuasan & Poin \\
\hline Sangat Puas & 4 \\
\hline Puas & 3 \\
\hline Tidak Puas & 2 \\
\hline Sangat Tidak Puas & 1 \\
\hline
\end{tabular}

\subsection{Metode Sampling}

Dalam inferensia statistik akan diperoleh kesimpulan mengenahi populasi, meskipun kita tidak mengamati keseluruhan individu yang ada dalam populasi (setyo, 2018). maka munculah metode sampling, sampel adalah bagian dari populasi.

\subsection{Quality Function Deployment (QFD)}

\subsubsection{Pengertian QFD}

Menurut (Garperz, 1997) Quality Function Deployment didefinisikan sebagai suatu proses atau mekanisme terstruktur untuk menentukan kebutuhan pelanggan dan menerjemahkan kebutuhan - kebutuhan itu kedalam kebutuhan teknis yang relevan, dimana masing-masing area fungsional dan level organisasi dapat mengerti dan bertindak.

\subsubsection{Manfaat QFD}

Manfaat dari aplikasi QFD menurut (afnani, 2018) dalam buku Lowe \& Ridway, antara lain :
a. Mengurangi time to market
b. Mengurangi perubahan design
c. Menurunkan biaya design dan manufaktur
d. Meningkatkan kualitas
e. Meningkatkan kepuasan pelanggan

\subsubsection{Proses QFD}

Pada realisasi penggunaan aplikasi, proses Quality Function Deploymen (QFD) terbagi 4 fase (crow, 2005). Model 4 fase ini menerjemahkan keinginan konsumen melalui beberapa tahap menuju proses perancangan prioduk. Setiap fase matrik yang terdiri dari kolom vertikal yang berisi What dan baris horizontal yang berisi How. What adalah kebutuhan konsumen dan How adalah cara untuk mencapainya.

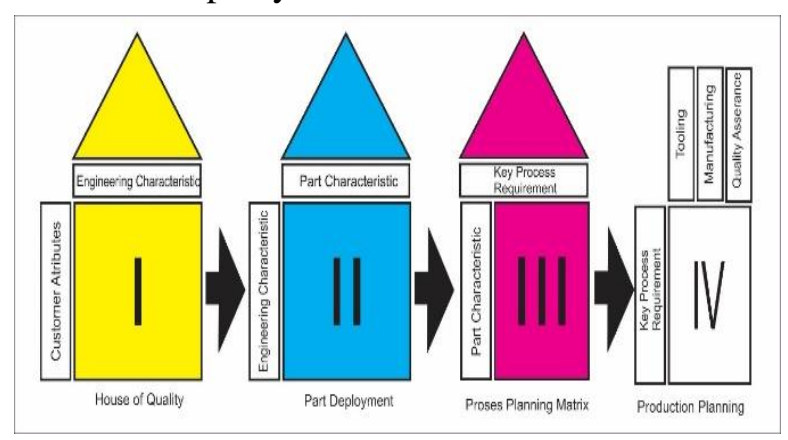

Gambar 1. Model empat fase dalam QFD

Pada gambar 1 diatas, memberikan gambaran tahapan suatu proses input sampai output yang diartikan mulai dari kebutuhan konsumen sampai pada cara mencapainya. Tahap I (satu) mulai dari persiapan dan perencanaan serta mengumpulkan voice of customer untuk mendapatkan atribut yang di observasi. Tahap II (dua) perancanaan part atau bagian apa saja yang dibutuhkan dalam pemenuhan kebutuhan konsumen. tahap III (tiga) perencanaan proses dalam pemenuhan kebutuhan yang diharapkan sehingga sesuai dengan apa yang di harapkan konsumen. Tahap IV (empat) perencanaan produksi sesuai dengan tahapan sebelumnya untuk mejadi suatu produk jadi atau output keinginan konsumen.

\section{Metode Penelitian}

Penyusunan analisis sistem dimulai dengan analisis kebutuhan pelanggan / warga (Voice of Customer). Analisis kebutuhan merupakan langkah awal dalam analisis sistem. Inventarisasi kebutuhan stakeholders yang dilakukan disini akan dilakukan sedemikian rupa sehingga diharapkan benar-benar merupakan aspirasi dari para stakeholders yang sesungguhnya, sehingga diperoleh jenis-jenis kebutuhan yang paling berpengaruh pada usaha penyusunan model tanpa mengabaikan kebutuhan lainnya. Langkah selanjutnya membuat House of Quality dengan model 
Quality Funtion Deployment (QFD) pada wilayah yang menjadi obyek penelitian yaitu desa manyar, desa duduk sampean, dan desa cerme.

Pengolahan data dilakukan dalam beberapa tahap yaitu pengolahan data tingkat kepentingan, pengolahan data tingkat kinerja atribut masing-masing desa. . Nilai tingkat kepentingan ini diperoleh berdasarkan persepsi pelanggan, jadi atribut yang memiliki tingkat nilai kepentingan yang lebih tinggi maka sangat penting menurut pelanggan.

Langkah selanjutnya adalah mengambil sample air dari masing-masing desa untuk diketahui kondisi struktur kadar airnya melalui div.litbang laboratorium milik teknik kimia yang ada di universitas muhammadiyah gresik.

Adapun tahapan yang dilakukan dalam penelitian ini adalah :
a. Tahap identifikasi masalah
b. Tahap rumusan masalah / tujuan penelitian
c. Tahap pengumpulan data
d. Tahap pengolahan data
e. Tahap kesimpulan
f. Tahap implementasi (prototype product)
Dibawah ini adalah kerangka penelitian yang dilakukan oleh tim peneliti.

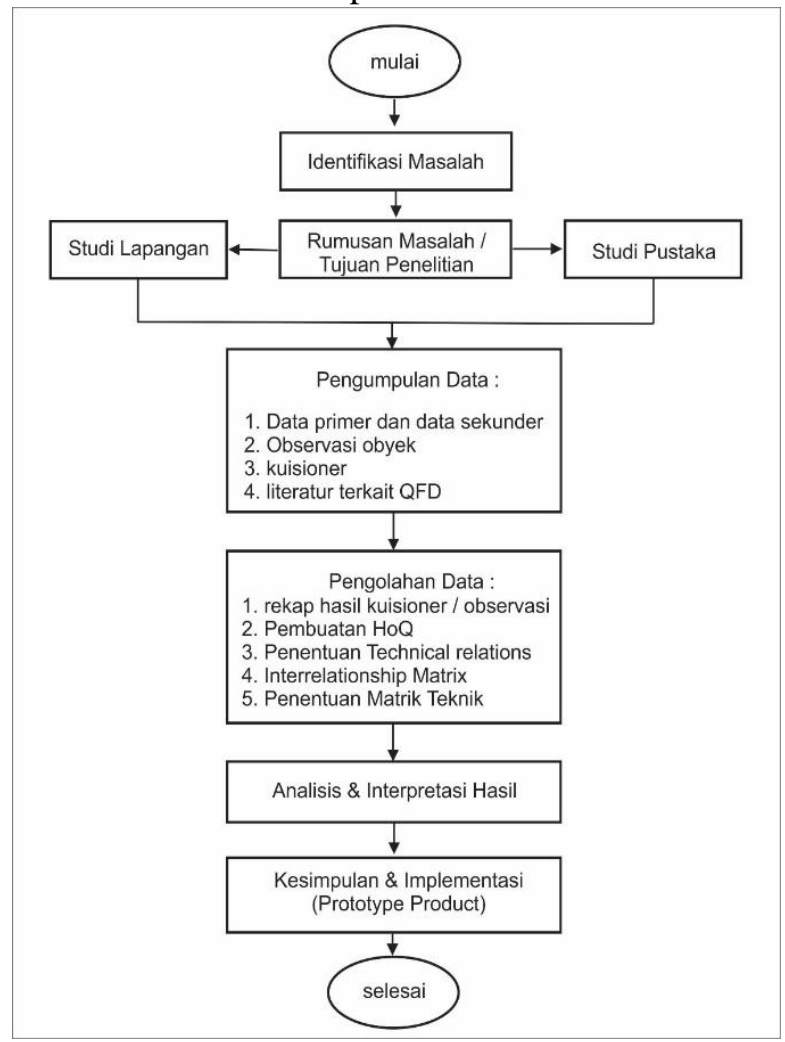

Gambar 2. Flowchat Penelitian

\section{Hasil dan Pembahasan}

Dalam proses pengolahan data ini digunakan bantuan software Microsoft excel 2016. Tabel 3 menampilkan hasil perhitungan mean tiap-tiap atribut dari tiap kuesioner

Tabel 3. Hasil perhitungan mean kuesioner

\begin{tabular}{|c|c|c|c|c|c|c|}
\hline \multirow[b]{2}{*}{ NO } & \multirow[b]{2}{*}{ Atribut } & \multicolumn{4}{|c|}{ Kuisioner } & \multirow[b]{2}{*}{ Target } \\
\hline & & $\begin{array}{c}\text { Tingkat } \\
\text { kepentingan }\end{array}$ & $\begin{array}{l}\text { Air Desa } \\
\text { Manyar }\end{array}$ & \begin{tabular}{|c|} 
Air Desa \\
Duduk \\
Sampean
\end{tabular} & \begin{tabular}{|c|} 
Air Desa \\
Cerme
\end{tabular} & \\
\hline 1 & Visual penampakan Air & 3,77 & 2,87 & 3,01 & 3,20 & 3,40 \\
\hline 2 & Visual Warna & 3,57 & 2,73 & 2,94 & 2,98 & 3,47 \\
\hline 3 & Aroma & 3,01 & 2,94 & 3,09 & 3,10 & 3,14 \\
\hline 4 & $\mathrm{pH}\left(25^{\circ} \mathrm{C}\right)$ & 2,87 & 2,69 & 2,83 & 2,85 & 3,04 \\
\hline 5 & Rasa & 2,90 & 2,53 & 2,89 & 2,69 & 3,13 \\
\hline 6 & Tercemar limbah & 2,73 & 2,67 & 2,93 & 2,90 & 2,97 \\
\hline 7 & Sumber mata air & 2,59 & 2,89 & 2,97 & 3,05 & 2,96 \\
\hline 8 & Terpengaruh musim / iklim & 3,20 & 2,96 & 3,05 & 3,10 & 2,93 \\
\hline 9 & Jenis Air & 3,53 & 2,67 & 3,00 & 3,12 & 3,23 \\
\hline
\end{tabular}

Berdasarkan hasil observasi yang dilakukan pada desa Manyar, desa Duduk Sampeyan dan Desa Cerme tentang kualitas air diwilayah tersebut, mendapatkan data dan hasil sebagai mana dibawah ini:

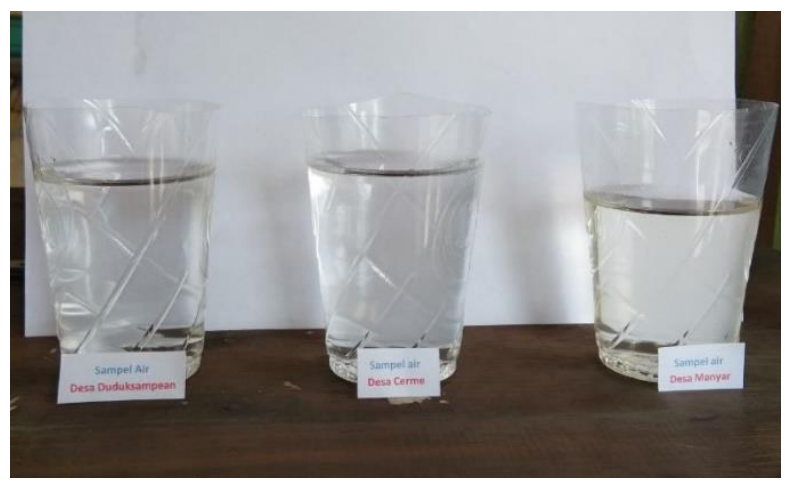

Gambar 3. Sampel air masing-masing Desa

Perbandingan kondisi air (sampling) pada masing - masing desa sebagai obyek penelitian

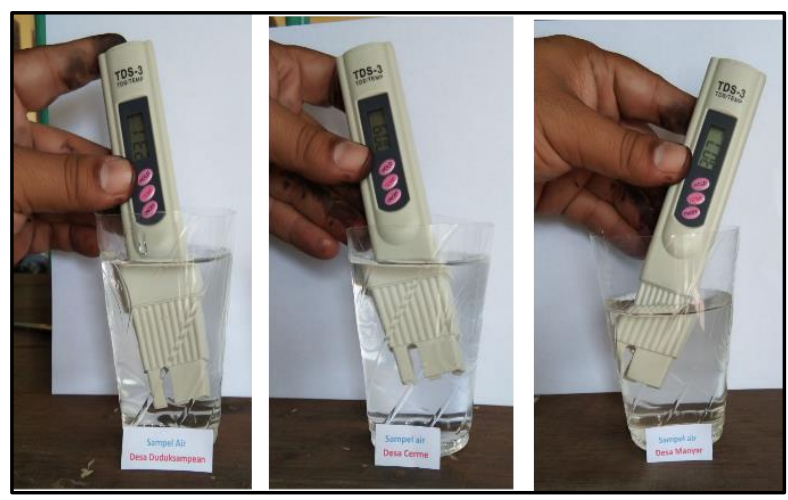

Gambar 4. tes kondisi TDS air masing desa 

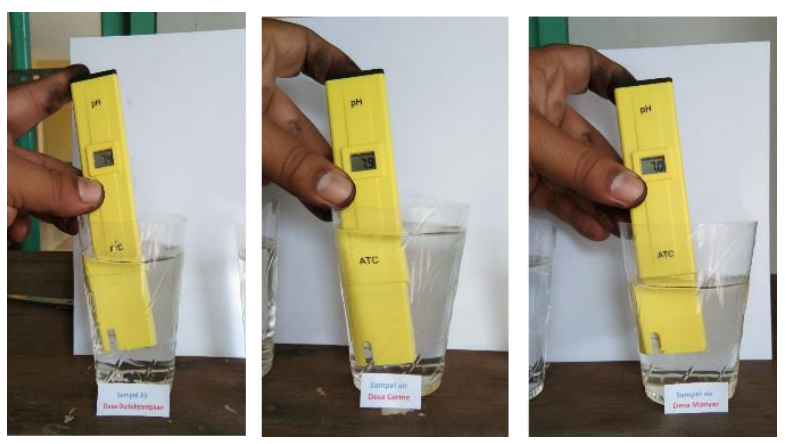

Gambar 5. Tes kondisi PH air masing desa

Dari gambar 4 dan 5 terdapat hasil masingmasing kondisi air di desa manyar, desa duduksampean dan desa cerme. Terdapat indikasi air di desa manyar dengan kualitas kurang baik. data Hasil lebih lengkap akan diberikan pada tabel dibawah ini :

Tabel 4. data uji kualitas air

\begin{tabular}{|c|c|c|c|c|c|c|}
\hline \multirow[b]{2}{*}{ No } & \multirow[b]{2}{*}{$\begin{array}{c}\text { Kriteria } \\
\text { Pengamatan }\end{array}$} & \multirow[b]{2}{*}{ Satuan } & \multirow[b]{2}{*}{ Metoda") } & \multicolumn{3}{|c|}{ Jenis Sample air } \\
\hline & & & & $\begin{array}{c}\text { Desa } \\
\text { Manyar }\end{array}$ & $\begin{array}{c}\text { Desa } \\
\text { DudukSampean }\end{array}$ & $\begin{array}{l}\text { Desa } \\
\text { Cerme }\end{array}$ \\
\hline 1 & \begin{tabular}{|l} 
Visual \\
penampakan
\end{tabular} & & & keruh & Keruh & Jernih \\
\hline 2 & Visual Warna & - & Organoleptik & kekuningan & kekuningan & $\begin{array}{c}\text { Tidak } \\
\text { berwarna }\end{array}$ \\
\hline 3 & Aroma & - & Organoleptik & Normal & Normal & Normal \\
\hline 4 & $\mathrm{pH}\left(25^{\circ} \mathrm{C}\right)$ & --. & pH Meter & 7.0 & 7.4 & 7.9 \\
\hline 5 & Conductivity & - & $\mathrm{pH}$ meter & 5.54 & 13.60 & 10.94 \\
\hline 6 & TDS & - & Tds Meter & 307 & 231 & 119 \\
\hline 7 & \begin{tabular}{|l} 
Total Disolved \\
Solid \\
\end{tabular} & $\mathrm{mS} / \mathrm{cm}^{3}$ & $\begin{array}{l}\text { Electrocondu } \\
\text { ctometer }\end{array}$ & 5.19 & 12.77 & 10.20 \\
\hline 8 & Salinitas & $\mathrm{ng} / \mathrm{L}$ & $\begin{array}{l}\text { Electrocondu } \\
\text { ctometer }\end{array}$ & 5.89 & 15.56 & 12.29 \\
\hline 9 & Klorida & $\mathrm{ng} / \mathrm{L}$ & $\begin{array}{l}\text { Electrocondu } \\
\text { ctometer }\end{array}$ & $1,460.61$ & $4,694.82$ & $3,686.30$ \\
\hline 10 & \begin{tabular}{|l|} 
Total \\
Kesadahan
\end{tabular} & $\mathrm{mg} / \mathrm{L}$ & Titrimetri & $1,058.63$ & 325.25 & 294.78 \\
\hline 11 & Calcium & $\mathrm{mg} / \mathrm{L}$ & Titrimetri & 474.43 & 142.91 & 127.23 \\
\hline 12 & Magnesium & $\mathrm{mg} / \mathrm{L}$ & Titrimetri & 136.70 & 42.67 & 39.21 \\
\hline 13 & Total Alkalinitas & $\mathrm{mg} / \mathrm{L}$ & Titrimetri & 385.68 & 113.03 & 108.65 \\
\hline 14 & Hidroksida & $\mathrm{mg} / \mathrm{L}$ & Titrimetri & 0.00 & 0.00 & 0.00 \\
\hline 15 & Carbonat & $\mathrm{mg} / \mathrm{L}$ & Titrimetri & 6.68 & 40.11 & 31.52 \\
\hline 16 & Bikarbonat & $\mathrm{mg} / \mathrm{L}$ & Titrimetri & 456.94 & 56.33 & 68.45 \\
\hline
\end{tabular}

Sumber : div. litbang Lab. Teknik kimia UMG

Dari data tersebut, tabel 3 menunjukan indikator tingkat kepentingan yang diharapkan oleh konsumen adalah 3 peringkat tertinggi dari 9 atribut antara lain atribut visual penampakan 3,77. Atribut visual warna 3,55. Dan atribut jenis air 3,53. Adapun indikator yang paling rendah dari target kepentingan konsumen adalah desa manyar, hasil yang ditunjukan atribut visual penampakan 2,87. Atribut visual warna 2,73. Dan atribut jenis air 2,67.
Tabel 5. Daftar Respon Teknis

\begin{tabular}{|c|c|c|}
\hline No & Atribut & Respon Teknis \\
\hline \multirow[t]{2}{*}{1} & \multirow{2}{*}{$\begin{array}{l}\text { Visual Penampakan } \\
\text { Air }\end{array}$} & Kandungan kadar air \\
\hline & & Pembersihan tempat waduk air \\
\hline \multirow[t]{3}{*}{2} & \multirow[t]{3}{*}{ Visual Warna } & Terkontaminasi limbah \\
\hline & & Penyaringan air \\
\hline & & Suhu lingkungan \\
\hline 3 & Aroma & Terkontaminasi limbah \\
\hline \multirow[t]{2}{*}{4} & \multirow[t]{2}{*}{$\mathrm{pH}$ air } & Suhu lingkungan \\
\hline & & Kandungan kadar air \\
\hline 5 & Rasa & Alat penyaringan air \\
\hline \multirow[t]{2}{*}{6} & \multirow[t]{2}{*}{ Tercemar limbah } & $\begin{array}{l}\text { Pembuatan saluran pembuangan } \\
\text { khusus }\end{array}$ \\
\hline & & Limbah diproses daur ulang \\
\hline 7 & Sumber mata air & Perbanyak pembuatan sumur \\
\hline 8 & $\begin{array}{l}\text { Terpengaruh musim / } \\
\text { iklim }\end{array}$ & $\begin{array}{l}\text { Memperluas atau memperbanyak } \\
\text { penampungan air }\end{array}$ \\
\hline \multirow[t]{2}{*}{9} & \multirow[t]{2}{*}{ Jenis Air } & Alat penyaringan air \\
\hline & & Proses filterisasi air \\
\hline
\end{tabular}

Tabel 6. Urutan Peringkat Nilai Prioritas Respon teknis

\begin{tabular}{|c|l|c|c|}
\hline Peringkat & Technical Relation & $\begin{array}{c}\text { Nilai } \\
\text { Prioritas }\end{array}$ & $\begin{array}{c}\text { Kontribusi } \\
\text { ternormalisasi }\end{array}$ \\
\hline 1 & Visual Warna & 3.10 & 0.310 \\
\hline 2 & Visual penampakan Air & 2.05 & 0.200 \\
\hline 3 & Jenis Air & 1.00 & 0.096 \\
\hline 4 & Rasa & 0.90 & 0.086 \\
\hline 5 & Aroma & 0.84 & 0.082 \\
\hline 6 & pH air & 0.76 & 0.073 \\
\hline 7 & Tercemar limbah & 0.68 & 0.065 \\
\hline 8 & Sumber mata air & 0.61 & 0.051 \\
\hline 9 & Terpengaruh musim / iklim & 0.52 & 0.048 \\
\hline
\end{tabular}

Hasil dari pengumpulan dan pengolahan data, maka didapat House of Quality pada obyek penelitian tersebut seperti gambar dibawah ini : 


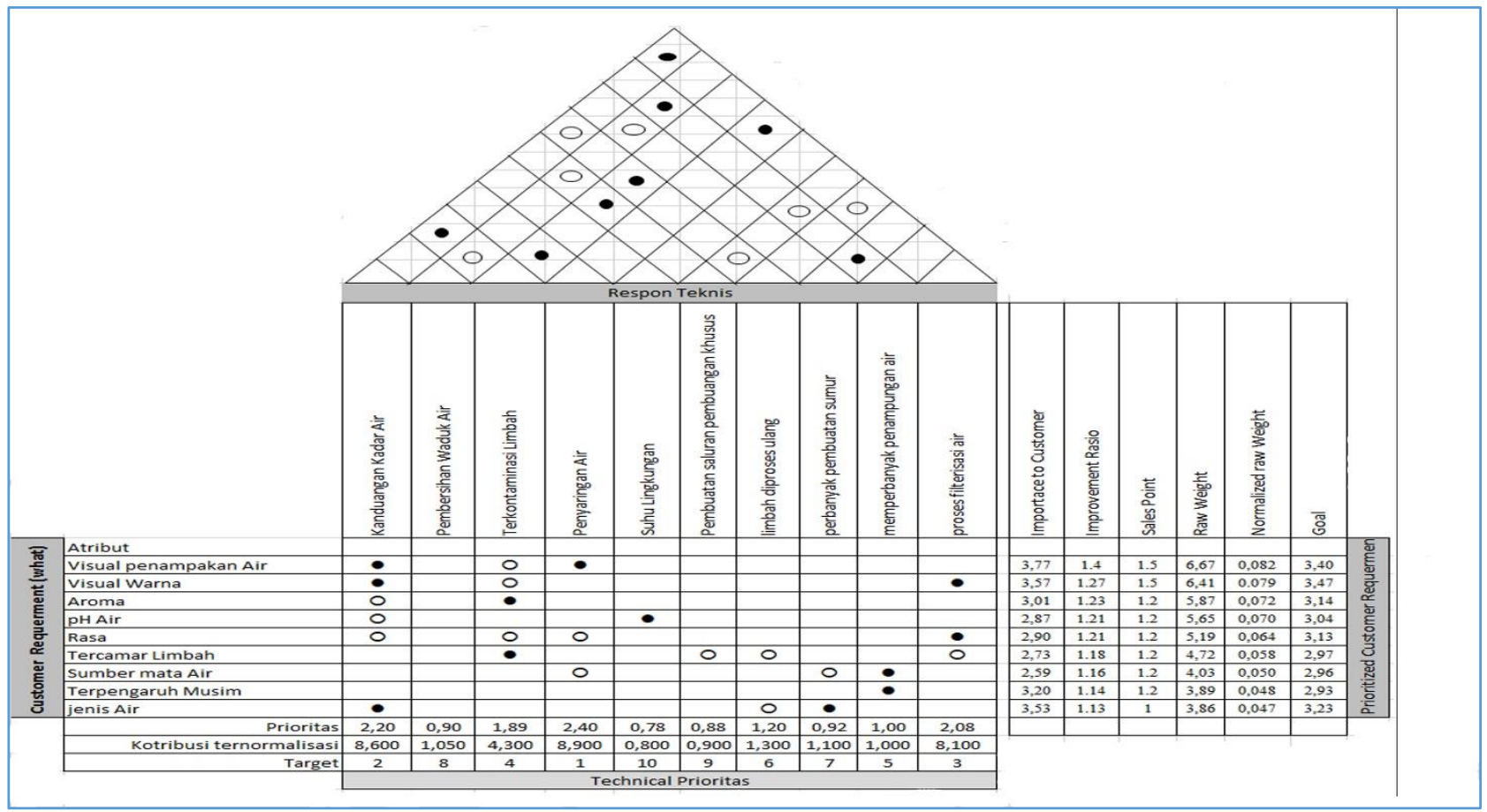

Gambar 6. Matrik House of Quality

\section{Kesimpulan dan \& Implementasi (Prototype Product)}

\subsection{Kesimpulan}

1. Atribut yang memiliki prioritas utama untuk dikembangkan atau ditingkatkan antara lain visual warna dengan nilai prioritas 3,1. Adapun desa yang perlu ditingkatkan kualitas nya desa manyar dengan indikator 2,73. Lebih rendah dari desa lainya

2. Berdasarkan hasil observasi di 3 desa terdahap hasil sample air dan analisis data matrik teknis dapat disimpulkan bahwa, untuk mendapatkan desain pengembangan produk yang memenuhi kebutuhan pelanggan, maka atribut yang perlu dikembangkan antara lain visual penampakan 3,77. Atribut visual warna 3,55 dan atribut jenis air 3,53.

\subsection{Implementasi (prototype product)}

Berdasarkan hasil kesimpulan diatas, maka perlu perbaikan kondisi air yang lebih baik dengan bantuan alat water filter pump, yang berfungsi melakukan proses penyulingan air agar menjadi lebih baik dan kandungan kadar airnya normal. Sedangkan komponen part yang didalam alat water filter pump, disesuaikan dengan kondisi kualitas air yang menjadi obyek penelitian :

\subsubsection{Prototype product:}

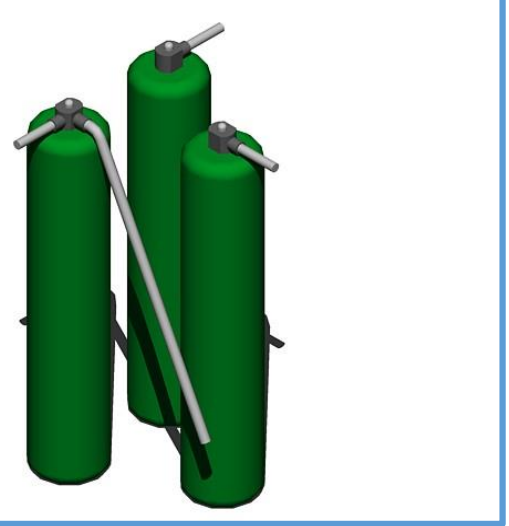

Gambar 7. Water Pump Filter

5.2.2 Spesifikasi Produk :

Terdiri dari 3 tabung dengan komposisi yang berbeda sebagai media filter.ukuran tabung diameter 3" dengan ketinggian $90 \mathrm{~cm}$. setiap tabung memiliki proses aliran air secara seri dari input sampai output. Dalam pembuatan alat ini didesain dengan bahan - bahan yang bisa didapat disekitar masyararakat agar mudah untuk produksi secara mandiri (teknologi tepat guna) serta ramah lingkungan untuk komposisi bahan yang digunakan (tidak mengakibatkan pencemaran lingkungan)

Tabung 1 :- proses input air dari sumber mata air

- Komposisi kapas alam,

Potasium Alum.

Tabung 2 :- Proses input air dari tabung 1 
- Komposisi bacteri bio ball, karbon active

Tabung 3 :- Proses input air dari tabung 2. Dan output air ke media

- Komposisi bio ring keramik, sedimen filter

Bahan Tabung : Pipa PVC 3"

Ukuran : $\Theta 3$ " $\mathrm{x} 90 \mathrm{~cm}$

Jumlah : 3 unit filter

Komponen : Tutup Drat 3"

PVC $3 / 4 "$

Knee $3 / 4$

SDL $3 / 4$

\section{Daftar Pustaka}

[1] Anisa Nanhidayah dan Alfan Purnomo, 2017 JURNAL TEKNIK ITS, "Sistem Penyediaan Air Bersih Desa Metatu dan Desa Kalipadang Kecamatan Benjeng Kabupaten Gresik Vol. 6 (2) hal 67-79 ISSN: 2337-3539

[2]Afnina, Pengaruh kualitas produk terhadap pelanggan, jurnal samudra vol.9 no.1 2018. E-issn 2614-1523, p 21-30

[3] Azizah, Penerapan metode Quality Funtion Deployment dalam memenuhi kepuasan konsumen pada industri komponen otomotif,Jurnal Teknik Industri, Vol. 19, No. 2, Agustus 2018, pp. 127-136 ISSN 1978-1431 print / ISSN 2527-4112

[4] Badan Pusat Statistik,2016. "Kecamatan Benjeng Dalam Angka 2016," Gresik

[5] BAPPEDA Gresik, 2015."Rencana Kerja Pembangunan Daerah Kabupaten Gresik Tahun 2015," Gresik.

[6] Cohen, L, 1995, Quality Function Deployment : How to make QFD Work for you, Addison wesley publishing Company, Massachusetts.

[7] Crow, Kerneth, A, 2002, Customer Docussed Development with QFD.

[8] Ulrich, Karl T dan Eppinger, Steven D, 2001, Perancangan dan pengembangan produk, penerbit salemba Teknika, Jakarta

[9] Lukman, wulandari , 2018. Peningkatan kualitas produk coklat dengan integrasi metode kano dan QFD, JTIUMM Vol 19 No.2. P 190-204

[10] N. I. Said and S. Yudo, 2008. "Masalah dan strategi penyediaan air bersih di Indonesia," Teknol. pengelolaan air minum Teor. dan pengalaman prakt., pp.80-106,2008.
[11] Setyo, Pengaruh kualitas produk dan harga terhadap kepuasan konsumen best autowork, performa, vol.1 no.6 februari 2017, 755-764

[12] Shilito,M.L., 1994, Advanced Quality Function Deployment: Linking Technology to market and Company Needs, John Willey and Sons Inc, UK.

[13] Sugiyono, 2004, Metode Penelitian Bisnis, Cetakan Ketujuh, Alfabeta, Bandung. [14] Wahyuni, Nursubiyantoro, Awaliah. 2020, perancangan dan pengembangan produk helm menggunakan QFD, OPSI vol 13 no.1. P 37-45. 